\title{
Vertebrate florivory of vascular epiphytes: the case of a bromeliad
}

\author{
Y. Palacios-Mosquera ${ }^{a}$, D. Mondragón ${ }^{a *}$ and A. Santos-Moreno ${ }^{a}$ \\ ${ }^{a}$ Centro Interdisciplinario de Investigación para el Desarrollo Integral Regional Unidad Oaxaca - CIIDIR, Instituto \\ Politécnico Nacional - IPN, Calle Hornos, 1003, CP 71230, Santa Cruz Xoxocotlán, Oaxaca, México \\ *e-mail: dmondragon@ipn.mx
}

Received: February 17, 2017 - Accepted: November 28, 2017 - Distributed: May 31, 2019

(With 3 figures)

\begin{abstract}
The avoidance of vertebrate herbivory is thought to be one of the possible drivers for the evolution of epiphytism. Scarce literature suggests that epiphyte herbivory is mainly related to insect attack on reproductive structures. In a pine-oak forest we observed almost all inflorescences of an epiphytic bromeliad (Tillandsia carlos-hankii) with signs of florivory; the degree of damage suggested that vertebrate herbivores could be involved. To assess the intensity of vertebrate florivory damage we recorded the percentage of damaged individuals in a $500 \mathrm{~m}^{2}$ plots during two flowering seasons. To identify possible vertebrate herbivores, we installed 20 mixed capture stations, 10 photo-traps focused on bromeliads and analyzed stomach contents of captured vertebrates. Florivory was observed on $62 \%$ of individuals during the first flowering season and $77 \%$ on the second; and average one individual lost $41 \%$ of reproductive structures. Vertebrates associated with florivory were a bird, Icterus bullockii (Aves, Passeriformes, Icteridae), a squirrel Sciurus aureogaster (Mammalia, Rodentia, Sciuridae), and mice, Peromyscus gratus, P. levipes and P. aztecus (Mammalia, Rodentia, Cricetidae). Our results suggest that vascular epiphytes are used as opportunistic resources for small vertebrates during seasons when preferred resources are scarce.
\end{abstract}

Keywords: birds, herbivory, Peromyscus, pine-oak forest, squirrels, Tillandsia.

\section{Florivores vertebrados de epífitas vasculares: o caso de uma bromélia}

\section{Resumo}

Acredita-se que a prevenção da herbivoria dos vertebrados é um dos possíveis impulsores da evolução da epífita. A literatura escassa sugere que a herbivora em epífitas está relacionada principalmente ao ataque de insetos as estruturas reprodutivas. Em uma floresta de pinheiros observamos que quase da todas as inflorescências de uma bromélia epífita (Tillandsia carlos-hankii) apresentavam sinais de florivoria; o grau de danos sugeria que herbívoros majores (vertebrados) pudessem estar envolvidos. Para avaliar a intensidade do dano de florivoria de vertebrados, registramos a porcentagem de indivíduos danificados em quadrantes de $500 \mathrm{~m}^{2}$ durante duas estações de florescimento. Para identificar possíveis herbívoros vertebrados, instalamos 20 estações de captura mista e analisamos o conteúdo estomacal de vertebrados capturados. Além disso, foram instaladas 10 foto-armadilhas focadas em bromélias. A florivoria foi observada em $62 \%$ dos indivíduos durante a primeira estação de floração e 77\% na segunda. Os vertebrados associados à florivoria foram pássaro, Icterus bullockii (Aves, Passeriformes, Icteridae), um esquilo Sciurus aureogaster (Mammalia, Rodentia, Sciuridae) e ratos, Peromyscus gratus, P. levipes e P. aztecus (Mammalia, Rodentia, Cricetidae). Assim, nossos resultados sugerem que epífitas vasculares são usadas como recurso facultativo para estes animais durante as estações, quando os recursos preferidos estão escassos.

Palavras-chave: pássaros, herbivoria, Peromyscus, floresta de pinheiro, esquilos, Tillandsia.

\section{Introduction}

Epiphytes, plants that live on other plants without taking nutrients directly from them (Benzing, 1990), represent approximately $9 \%$ of world vascular plant diversity, with 27, 614 species (Zotz, 2013). These plants play an important roles in ecosystems, increasing their diversity (Nieder et al., 2001; Barbosa et al., 2015), providing food, water and shelter for many organisms as reptiles, insects and microorganisms (Araújo et al., 2007; Cruz-Ruíz et al.,

2012; Pederassi et al., 2012; Brandt et al., 2017), as well as participating in water and nutrient cycles (Coxson and Nadkarni, 1995; Van Stan and Pypker, 2015).

One of the drivers of the evolution of epiphytism is thought to be the avoidance of vertebrate herbivory (Zotz, 2016). Vertebrate herbivory has a negative impact on the growth, reproduction and survival of plants, owing to the loss of photosynthetic or reproductive tissue 
(Grant-Hoffman and Barboza, 2010; Pacheco, 2011; Waal et al., 2012). The degree of damage depends on the phenological stage of the plant, the amount of tissue removed, the frequency of damage and the resilience of the plant to damage (Crawley, 2009). Florivory, which includes consumption of flowers, damage to bracts, sepals, petals, stamens, pistils, pollen and ovules (McCall and Irwin, 2006), is a kind of herbivory that directly results in the loss of reproductive tissue and indirectly affects the pollinator behavior (Canela and Sazima, 2003; McCall and Irwin, 2006; Cascante-Marín et al., 2009).

Little is known about vascular epiphyte florivory (Benzing, 1990; Zotz, 2016). Florivory in vascular epiphytes is effected mainly by insects (Canela and Sazima, 2003; Cascante-Marín et al., 2009; Orozco-Ibarrola et al., 2015; Nunes et al., 2016), but two reports of vertebrate florivory are known. García-Franco and Rico-Gray (1991) report severe damage to inflorescences of Tillandsia deppeana Steudel (Bromeliaceae) by squirrels in a cloud forest, and Aguilar-Rodríguez et al. (2014) report the consumption of pollen of T. macropetala Wawra by a mouse species of the genus Peromyscus Gloger, 1841 in a tropical montane cloud forest.

To contribute to the scanty knowledge of epiphytic florivory we a) quantified the magnitude of florivory of an epiphytic bromeliad Tillandsia carlos-hankii Matuda, and $b$ ) established possible vertebrates linked to florivory in a pine-oak forest.

\section{Materials and Methods}

The population of Tillandsia carlos-hankii studied is located in a temperate pine-oak forest in an area known as Los Leones (coordinates $96^{\circ} 35^{\prime} \mathrm{W}$ and $17^{\circ} 11^{\prime} \mathrm{N}$; altitude 2,145 m a. s. 1.), in the Municipality of Santa Catarina Ixtepeji, Ixtlán de Juárez District, Oaxaca, Mexico. Mean annual temperature is about $18.3^{\circ} \mathrm{C}$ and mean annual rainfall is $759.3 \mathrm{~mm}$ (Servicio Meteorológico Nacional, 2011). Tree and brush vegetation consists principally of Pinus spp. (Pinaceae) and Quercus spp. (Fagaceae) (Zacarías-Eslava and Castillo, 2010). The epiphytic vegetation includes some Tillandsia L., Pleopeltis Humb. \& Bonpl. ex Willd. (Polypodiaceae) and Polypodium L. species (Victoria, 2009).

Tillandsia carlos-hankii, an epiphytic tank bromeliad, is endemic to the state of Oaxaca and grows in pine-oak forests at elevations between 1,900 and 2,900 $\mathrm{m}$ a.s.l. This species has a floral axis that measures between 57 and $70 \mathrm{~cm}$. The scape is robust and its bracts are imbricated, with the lower part green and the upper third red. The inflorescence is cylindrical, with bracts of different sizes that vary from the base (wider) to the tip, and with spikes that are short and stipitate. The floral bracts are triangular, measuring $2.5 \times 1.2 \mathrm{~cm}$, and are densely lepidoted. The flowers on the spikes have lanceolate sepals and tubular petals that are of a pale green color and are from 5.2 to $5.7 \mathrm{~cm}$ long; the fruits are capsules with plumose seed appendages (Smith and Downs, 1977; Espejo-Serna et al., 2004). Its flowering season is from January to May. This specie is monocarpic, hermaphrodite and self-compatible. It shows a mixed mating system (Mondragón and Ramírez-Morillo, 2008), and is hummingbird-pollinated (Fernández-Rios, 2012)

Vertebrate fauna of Santa Catarina Ixtepeji is represented by Canis latrans Say, 1823, Urocyon cinereoargenteus Schreber, 1775, Lynx rufus Schreber, 1777, Leopardus wiedii Schinz, 1821, Taxidea taxus Schreber, 1777, Spilogale putorius Linnaeus, 1758, S. gracilis Merriam, 1890), Mustela frenata Lichtensein, 1831, Bassariscus astutus Lichtenstein, 1830, Nasua narica Linnaeus, 1776, Procyon lotor Linnaeus, 1758, Sciurus aureogaster F. Cuvier, 1829, Sylvilagus floridanus J. A. Allen, 1890, Didelphis marsupialis Linnaeus, 1758, Microtus sp. Schrank, 1798, Peromyscus spp., Sigmodon hispidus Say and Ord, 1825 and Orthogeomys spp. Merriam, 1895 (Botello-López, 2004; Cruz-Espinoza et al., 2010).

We evaluated the intensity of florivory as the percentage of damaged individuals in the population sample and the percentage of structures lost per individual. For the former a $500 \mathrm{~m}^{2}$ plot was established, in which all the individuals with inflorescences were labeled and evaluated. Individuals were monitored monthly from December 2011 to February 2013: a period that included two flowering seasons. During every visit, we counted the number of damaged individuals to estimate their percentage. At a distance of $20 \mathrm{~m}$ from the $500 \mathrm{~m}^{2}$ plot, we chose 20 undamaged individuals of T. carlos-hankii. These individuals were marked and the total number of bracts and spikes on their inflorescence was recorded. Monthly censuses were carried out to record the number of damaged structures to estimate the percentage of structures lost. We used a Chi-squared test of independence (Zar, 1999) on a $2 \times 2$ contingency table to compare the percentage of damaged inflorescences between seasons.

To identify the potential species of vertebrates that could damage the reproductive structures of $T$. carlos-hankii, 20 stations were set up in trees at heights between 2 and $13 \mathrm{~m}$ to capture small mammals. We looked for small mammals because epiphyte florivory is linked to small rodents (García-Franco and Rico-Gray, 1991; Aguilar-Rodríguez et al., 2014), and because there were no reports at our sites of big, tree-dwelling vertebrates that could reach epiphytes. Stations comprised two types of traps: a folding, aluminum Sherman trap $(7.6 \times 8.8 \times 22.8 \mathrm{~cm})$ and a Tomahawk trap $(25 \times 30 \times 82 \mathrm{~cm})$, baited with sunflower seeds and vanilla extract. The two types of traps were placed independently on trees which showed branches with adequate thickness to support traps and had at least one individual of T. carlos-hankii with inflorescence. The traps were open for 24 hours a day over five consecutive days in every month from January 2012 to January 2013, giving a capturing effort of 1,300 traps/night (20 traps $\times 65$ nights).

Further sampling of vertebrates was conducted with 10 camera traps (Bushnell Trophy Cam XLT, Olathe, Kansas, U.S.A.) set up outside the study plot between 3 and $15 \mathrm{~m}$ above the ground. These cameras were permanently active throughout the year in which the 
population of T. carlos-hankii was followed, and yielded a sampling effort of 8,760 hours in 365 days/camera.

Each specimen captured was taxonomically identified at the Animal Ecology Laboratory, Centro Interdisciplinario de Investigación para el Desarrollo Integral Regional, Oaxaca Unit. After euthanization by neck dislocation, the stomach was extracted and preserved in alcohol at $70 \%$. The Hornung Leoni's (2011) technique was applied to detect the presence of any peltate trichomes of Tillandsia in the stomach contents of the captured rodents. Peltate trichomes are elaborate epidermal structures of bromeliads; the most complex trichomes belong to the subfamily Tillandsioideae (Benzing, 1980). Five samples were obtained from each stomach, and each sample was placed on a slide and 20 optical fields were observed with a light microscope at magnifications of $10 \times$ and $40 \times$.

\section{Results}

Although inflorescences in T. carlos-hankii started to form in August, florivory began only in November, when inflorescences were fully developed and floral bracts had acquired their characteristic orange color. Florivory damage comprised the complete loss of spikes and tissue loss in bracts (Figure 1); it reached its maximum intensity in February, when flowers were exerted. Attacks reduced in May when no more flowers were available. We did not observe vertebrate herbivory on fruits during their production.

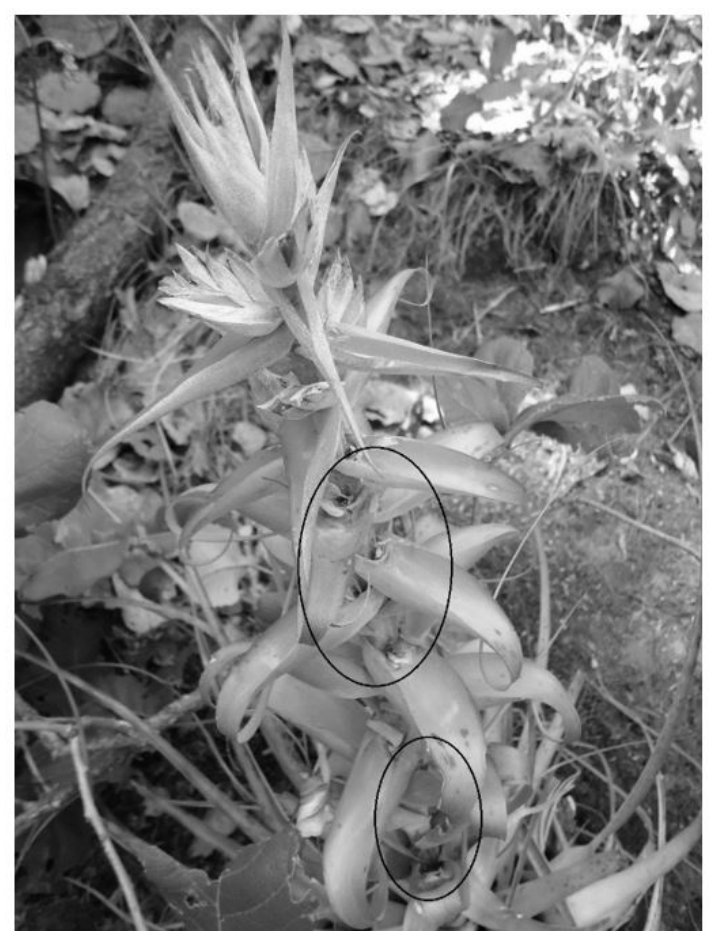

Figure 1. Florivory of Tillandsia carlos-hankii at Santa Catarina Ixtepeji in 2012.
The percentages of damaged individuals did not vary between the flowering seasons $\left(\chi^{2}=1.91, d . f .=1, P>0.05\right)$. During the first season $62 \%$ of the 110 bromeliads that produced inflorescences were damaged, whereas in the second flowering season, of the 22 bromeliads that produced inflorescences, $77 \%$ were damaged. At the individual level, the damage was smaller, in average an individual loss $41 \%$ of its structures (37\% of its spikes and $4 \%$ of its bracts). We were able to differentiate the damage by insect from those by vertebrate, because the former attack the base of the spikes promoting its fall, while the later attack floral bracts, spikes and the rachis of the inflorescence, where spikes and bracts are insert (Palacios-Mosquera, 2013).

Fifty-one rodents from three species were captured in the traps, all belonging to the genus Peromyscus (class Mammalia, order Rodentia, family Cricetidae): Osgood's mouse (P. gratus Merriam, 1898; 13 individuals), nimble-footed deer mouse (P. levipes Merriam, 1898; 27 individuals), and Aztec mouse ( $P$. aztecus Saussure, $1860 ; 11$ individuals). Only one peltate trichome was seen in one sample from $P$. levipes (Figure 2).

Two vertebrate species visiting $T$. carlos-hankii inflorescences were detected by the camera traps: a Mexican gray squirrel (Sciurus aureogaster F. Cuvier, 1829; class Mammalia, order Rodentia, family Sciuridae) (Figure 3), and a Bullock's oriole (Icterus bullockii Swainson, 1827; class Aves, order Passeriformes, family Icteridae). Twenty-five records of presence of squirrels were obtained by phototraps, while only one record was obtained for I. bullockii

\section{Discussion}

\subsection{Florivory damage}

The loss of up to $41 \%$ of reproductive structures per individual could be detrimental to Tillandsia carlos-hankii. As McCall and Irwin (2006) point out, "Florivores also have direct costs to plants by consuming resource sinks

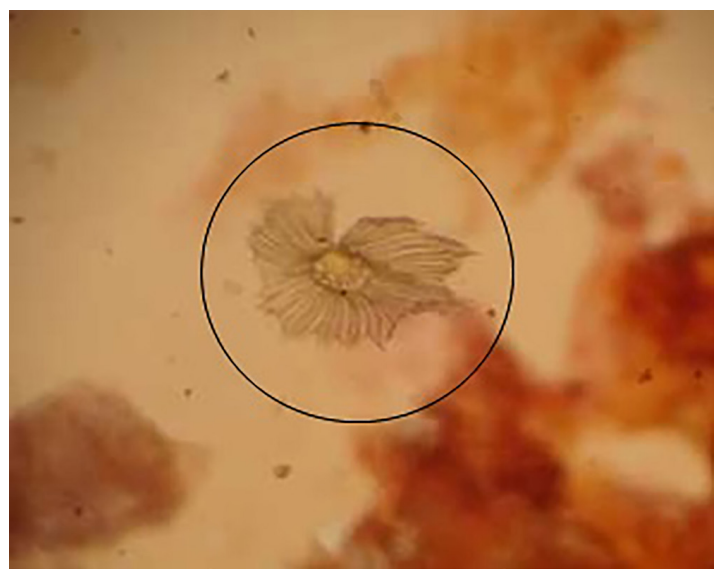

Figure 2. Peltate trichome present in the stomach contents of the nimble-footed mouse (Peromyscus levipes). 


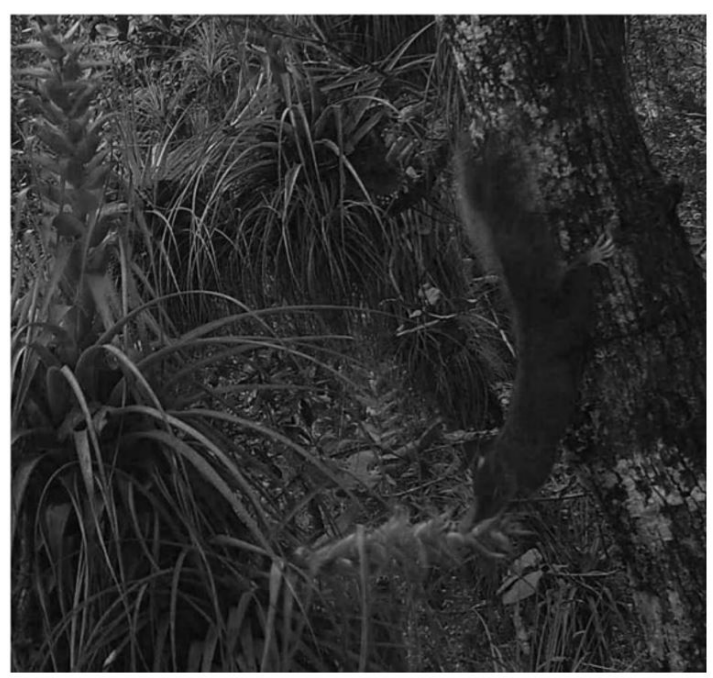

Figure 3. A Mexican gray squirrel (Sciurus aureogaster) consuming a Tillandsia carlos-hankii inflorescence.

(i.e. flowers) in resource-limited environments, especially in cases where plants reabsorb nitrogen and phosphorous from petals once fertilization has occurred", or when reproductive structures are photosynthetically active. This could be the case for vascular epiphytes, which grow in nutrient-limited habitats (Benzing, 1990; Zotz and Hietz, 2001; Zotz, 2016) and invest up to $30 \%$ of total plant biomass in reproductive structures (Zotz and Richter, 2006; Zotz, 2016). To the best of our knowledge, the reabsorption of nitrogen and phosphorous from petals in vascular epiphytes has not been studied. Nevertheless, epiphytic plants, especially epiphytic bromeliads, are known to have evolved novel strategies to access to nutrients (Benzing, 1990; 2000), so a similar mechanism may exist in vascular epiphytes for which phosphorus, and nitrogen to a lesser extent, are the main limiting nutrients for growth and reproduction (Zotz and Richter, 2006; Cardelús and Mack, 2010). Even more limited than nutrients, is the supply of water in epiphytic habitats (Zotz, 1999; Zotz and Hietz, 2001; Zotz, 2016). Florivory could result in increased water stress because damaged petals may lose water through increased transpiration, or simply through leakage (McCall and Irwin, 2006), but again, it will necessary to test this hypothesis.

Colored reproductive bracts attract pollinators to epiphytic bromeliads. After flowering ends, the bracts turn green and photosynthesize, thus boosting the supply of resources to the plant during fruit maturation (Benzing and Friedman, 1981). Such is the case for T. carlos-hankii, in which orange reproductive bracts turn green after flowering and fruit takes over a year to mature (Mondragón and Ramírez-Morillo, 2008). Thus, the loss of almost $4 \%$ of bracts could result in diminished photosynthetic rates that negatively affect the fitness of $T$. carlos hankii, but as in the former case, experiments will be needed to support this.

\subsection{Vertebrate identification}

The fact that members of the genus Peromyscus have been reported eating pollen of an epiphytic bromeliad (Aguilar-Rodríguez et al., 2014), together with the knowledge that Peromyscus species eat a wide variety of plants and arthropods, being highly opportunistic (Douglas, 1969), suggests they can use floral resources of epiphytic bromeliads. Although three species of Peromyscus were captured, the use of epiphytic bromeliads in our study place seems to be negligible, since only one T. carlos-hankii trichome was found in one P. levites stomach. This could be the result of accidental ingest when the animal was looking for water or arthropods inside T. carlos-hankii's tanks.

Squirrels can opportunistically feed on epiphytic bromeliads. The Mexican gray squirrel (Sciurus aureogaster) was reported as being responsible for the florivory of an epiphytic bromeliad, $T$. deppeana, in a cloud forest, where $63 \%$ of individuals were damaged. Damage included the loss of spikes part to the detachment of the spike and occurred during the driest months of the year, when other resources for squirrels are scarce (García-Franco and Rico-Gray, 1991). We found the same florivory pattern for T. carlos-hankii in this pine-oak forest, where T. carlos-hankii flowers during the dry season when there is less availability of resources (Franco-Méndez, 2008; García-Jarquín, 2008). We recorded individuals of $S$. aureogaster feeding on inflorescences of T. carlos-hankii. Squirrels removed the spikes with buds and flowers during dry season, when cones of pine and acorns were dry, and presumably contained high levels of cellulose (Dickmann and Kozlowski, 1969). Squirrels are unable to process cellulose, so they need food rich in protein, fat and carbohydrates. For this reason, $S$. aureogaster varies its diet widely to feed upon whichever type of food that is abundant at a particular season of the year (Brown and McGuire, 1975), in this case, the nutrient rich reproductive structures of epiphytic bromeliads (García-Franco and Rico-Gray, 1991; Overdorff, 1992; Zotz, 2016).

The damage caused by S. aureogaster to T. carloshankii goes beyond the loss of reproductive structures. It also potentially interferes with the behavior of its pollinators. Although we did not measure this, we observed that the activity periods of $S$. aureogaster (7-11 a.m. and 1-6 p.m., according to our photo records), overlapped with the activity periods of hummingbirds (6-9 a.m. and 5-7 p.m.; C. Fernández-Rios pers. obs.). The presence of squirrels in the inflorescences may discourage visits by hummingbirds, as the case of Aechmea pectinata, that the presence of a crab (Armeses angustipes) reduces the rates of hummingbird visits (Canela and Sazima, 2003), promoting self-pollination (Charlesworth and Charlesworth, 1987; Naito et al., 2005).

We found no reports of any bird as florivores of vascular epiphytes. We saw an I. bullockii visiting the inflorescences of $T$. carlos-hankii, and its behavior suggested that it was looking for nectar. Montesino (2011) reported that I. bullockii consumes nectar and occasionally cuts flowers in order to optimize its activity. As in the case of squirrels and mice, oriole birds (Icterus spp.) have a varied diet that 
includes arthropods, nectar, pollen, fruits and seeds (Stiles and Skutch, 1989; Scharf and Kren, 1997).

Our results suggest that vascular epiphytes are opportunistic sources of food for small vertebrates seeking to supplement their diets when their preferred sources of food (arthropods, cones and acorns) are less available. Further work is necessary to evaluate the impacts of florivory on vascular epiphytes. The impacts that the loss of reproductive structures have on these oligotrophic and xerophytic organisms may exceed those faced by other growth forms in nutrient- and water-rich habitats.

\section{Acknowledgements}

We are grateful for the financial support provided by projects SIP-20130738 and SIP-20131154 from the Instituto Politécnico Nacional de México. El Consejo Nacional de Ciencia y Tecnología awarded a scholarship to Y. Palacios-Mosquera for her master's studies; Mondragón and Santos-Moreno received a Comisión de Operación y Fomento de Actividades Académicas del Instituto Politécnico Nacional scholarship. We thank Sheeba Sreenivasan for editing the English version of our manuscript.

\section{References}

AGUILAR-RODRÍGUEZ, P.A., MACSWINEY G, M.C., KRÖMER, T. and GARCÍA-FRANCO, J.G., 2014. Pollen consumption by free-living mice. Acta Theriologica, vol. 59, no. 2, pp. 361-365. http://dx.doi.org/10.1007/s13364-013-0164-7.

ARAÚJO, V.A., MELO, S.K., ARAÚJO, A.P.A., GOMES, M.L.M. and CARNEIRO, M.A.A., 2007. Relationship between invertebrate fauna and bromeliad size. Brazilian Journal of Biology $=$ Revista Brasileira de Biologia, vol. 67, no. 4, pp. 611-617. PMid:18278311.

BARBOSA, M.D., BECKER, D.F.P., CUNHA, S., DROSTE, A. and SCHMITT, J.L., 2015. Vascular epiphytes of the Atlantic Forest in the Sinos River basin, state of Rio Grande do Sul, Brazil: richness, floristic composition and community structure. Brazilian Journal of Biology $=$ Revista Brasileira de Biologia, vol. 75, no. 2, (suppl.), pp. 25-35. http://dx.doi.org/10.1590/1519-6984.0913. PMid:26270210.

BENZING, D.H., 1980. The biology of the bromeliads. USA: Mad River Press, Inc. 305 p.

BENZING, D.H., 1990. Vascular epiphytes: general biology and related biota. USA: Cambridge University Press. 354 p. http:// dx.doi.org/10.1017/CBO9780511525438.

BENZING, D.H., 2000. Bromeliaceae: profile of an adaptive radiation. USA: Cambridge University Press. 690 p. http://dx.doi. org/10.1017/CBO9780511565175.

BENZING, D.H. and FRIEDMAN, W.E., 1981. Patterns of foliar pigmentation in Bromeliaceae and their adaptive significance. Selbyana, vol. 5, no. 3, pp. 224-240.

BOTELLO-LÓPEZ, F.J., 2004. Comparación de cuatro metodologías para determinar la diversidad de carnívoros en Santa Catarina Ixtepeji, Oaxaca. México: Facultad de Ciencias, Universidad Nacional Autónoma de México, p. 47. Bachelor's dissertation in Biology.
BRANDT, F.B., MARTINSON, G.O. and CONRAD, R., 2017. Bromeliad tanks are unique habitats for microbial communities involved in methane turnover. Plant and Soil, vol. 410, no. 1, pp. 167-179.

BROWN, L.N. and MCGUIRE, R.J., 1975. Field ecology of the exotic Mexican red-bellied squirrel in Florida. Journal of Mammalogy, vol. 56, no. 2, pp. 405-419. http://dx.doi.org/10.2307/1379370.

CANELA, M.B.F. and SAZIMA, M., 2003. Florivory by the crab Armases angustipes (Grapsidae) influences hummingbird visits to Aechmea pectinata (Bromeliaceae). Biotropica, vol. 35, no. 2, pp. 289-294. http://dx.doi.org/10.1111/j.1744-7429.2003.tb00287.x.

CARDELÚS, C.L. and MACK, M.C., 2010. The nutrient status of epiphytes and their host trees along an elevational gradient in Costa Rica. Plant Ecology, vol. 207, no. 1, pp. 25-37. http:// dx.doi.org/10.1007/s11258-009-9651-y.

CASCANTE-MARÍN, A., WOLF, J.H.D. and OOSTERMEIJER, J.G.B., 2009. Wasp florivory decreases reproductive success in an epiphytic bromeliad. Plant Ecology, vol. 203, no. 1, pp. 149-153. http://dx.doi.org/10.1007/s11258-008-9522-y.

CHARLESWORTH, D. and CHARLESWORTH, B., 1987. Inbreeding depression and its evolutionary consequences. Annual Review of Ecology and Systematics, vol. 18, no. 1, pp. 237-268. http://dx.doi.org/10.1146/annurev.es.18.110187.001321.

COXSON, D.S. and NADKARNI, N.M., 1995. Ecological roles of epiphytes in nutrient cycles of forest ecosystems. In: M.D. LOWMAN and N.M. NADKARNI, eds. Forest canopies. San Diego: Academic Press, chap. 20, pp. 495-543.

CRAWLEY, M.J., 2009. Plant-herbivore dynamics. In: M.J. CRAWLEY, ed. Plant ecology. USA: Blackwell Publishing Ltd., pp. 401-474.

CRUZ-ESPINOZA, A., PÉREZ, G.E.G. and SANTOS-MORENO, A., 2010. Dieta del Coyote (Canis Latrans) en Ixtepeji, Sierra Madre de Oaxaca, México. Naturaleza y Desarrollo, vol. 8, no. 1, pp. 33-45.

CRUZ-RUIZ, G.I., MONDRAGÓN, D. and SANTOS-MORENO, A., 2012. The presence of Abronia oaxacae (Squamata: Anguidae) in tank bromeliads in temperate forests of Oaxaca, Mexico. Brazilian Journal of Biology $=$ Revista Brasileira de Biologia, vol. 72, no. 2, pp. 337-341. PMid:22735142.

DICKMANN, D.I. and KOZLOWSKI, T.T., 1969. Seasonal variations in reserve and structural components of Pinus resinosa cones. American Journal of Botany, vol. 56, no. 5, pp. 515-520. http://dx.doi.org/10.1002/j.1537-2197.1969.tb07564.x.

DOUGLAS, C.L., 1969. Comparative ecology of pinyon mice and deer mice in Mesa Verde National Park, Colorado. University of Kansas Publications. Museum of Natural History, vol. 18, no. 5, pp. 421-504.

ESPEJO-SERNA, A., LÓPEZ-FERRARI, A.R., RAMÍREZMORILLO, I., HOLST, B.K., LUTHER, H.E. and TILL, W., 2004. Checklist of Mexican Bromeliaceae with notes on species distribution and levels of endemism. Selbyana, vol. 25, no. 1, pp. 33-86.

FERNÁNDEZ-RIOS, C., 2012. Variación fenotípica de caracteres reproductivos en Tillandsia carlos-hankii Matuda (Bromeliaceae), en la región de Santa Catarina Ixtepeji, Oaxaca. México: Instituto Politécnico Nacional, 96 p. Master's dissertation in Conservation and Management of the Natural Resources. 
FRANCO-MÉNDEZ, M.A.D., 2008. Diversidad de artrópodos presentes en Tillandsia carlos-hankii y T. oaxacana. México: Instituto Politécnico Nacional, 106 p. Master's dissertation in Conservation and Management of the Natural Resources.

GARCIA- FRANCO, J.G. and RICO-GRAY, V., 1991. Biología reproductiva de Tillandsia deppeana Steudel (Bromeliaceae) en Veracruz, México. Brenesia, no. 35, pp. 61-79.

GARCÍA-JARQUÍN, M.I., 2008. Macroartrópodos asociados a la bromelia Tillandsia prodigiosa (Lem.) Baker en dos localidades de Santa Catarina Ixtepeji, Oaxaca. Mexico: Instituto Politécnico Nacional, 84 p. Master's dissertation in Conservation and Management of the Natural Resources.

GRANT-HOFFMAN, M.N. and BARBOZA, P.S., 2010. Herbivory in invasive rats: criteria for food selection. Biological Invasions, vol. 12, no. 4, pp. 805-825. http://dx.doi.org/10.1007/ s10530-009-9503-7.

HORNUNG LEONI, C.T., 2011 [viewed 2 May 2012]. Anatomía foliar de Tillandsia complanata Benth. Pittieria [online], vol. 39, no. 35, pp. 133-142. Available from: http://www.saber.ula.ve/ bitstream/123456789/34363/1/09.pdf.

MCCALL,A.C. and IRWIN, R.E., 2006. Florivory: the intersection of pollination and herbivory. Ecology Letters, vol. 9, no. 12, pp. 1351-1365. http://dx.doi.org/10.1111/j.1461-0248.2006.00975.x. PMid:17118009.

MONDRAGÓN, D. and RAMÍREZ-MORILLO, I., 2008. Final report of the Project Diversidad, fenología floral e interacción animal-planta de las bromelias epifitas presentes a lo largo del gradiente altitudinal del bosque de pino-encino de Ixtepeji, en la Sierra Norte de Oaxaca. Oaxaca-México: SEP-CONACYT 2004-CO1-48136.

MONTESINO, F., 2011. Preliminary study of the nectarivorous avifauna in the Ethnobotanical Garden of Oaxaca de Juárez, Oaxaca. México: Instituto Tecnológico del Valle de Oaxaca, 102 p. Bachelor's dissertation in Biology.

NAITO, Y., KONUMA, A., IWATA, H., SUYAMA, Y., SEIWA, K., OKUDA, T., LEONG LEE, S., MUHAMMAD, N. and TSUMURA, Y., 2005. Selfing and inbreeding depression in seeds and seedlings of Neobalanocarpus heimii (Dipterocarpaceae). Journal of Plant Research, vol. 118, no. 6, pp. 423-430. http:// dx.doi.org/10.1007/s10265-005-0245-z. PMid:16283070.

NIEDER, J., PROSPERÍ, J. and MICHALOUD, G., 2001. Epiphytes and their contribution to canopy diversity. In: K.E. LINSENMAIR, A.J. DAVIS, B. FIALA and M.R. SPEIGHT, eds. Tropical forest canopies: ecology and management. Dordrecht: Springer Forestry Sciences, vol. 69, pp. 51-63. http://dx.doi. org/10.1007/978-94-017-3606-0_5.

NUNES, C.E., PEÑAFLOR, M.F.G., BENTO, J.M.S., SALVADOR, M.J. and SAZIMA, M., 2016. The dilemma of being a fragrant flower: the major floral volatile attracts pollinators and florivores in the euglossine-pollinated orchid Dichaea pendula. Oecologia, vol. 182, no. 4, pp. 933-946. http://dx.doi.org/10.1007/s00442016-3703-5. PMid:27538674.

OROZCO-IBARROLA, O.A., FLORES-HERNANDEZ, P.S., VICTORIANO-ROMERO, E., CORONA-LÓPEZ, A.M. and FLORES-PALACIOS, A., 2015. Are breeding system and florivory associated with the abundance of Tillandsia species (Bromeliaceae)? Botanical Journal of the Linnean Society, vol. 177, no. 1, pp. 50-65. http://dx.doi.org/10.1111/boj.12225.
OVERDORFF, D.J., 1992. Differential patterns in flower feeding by Eulemur fulvus rufus and Eulemur rubriventer in Madagascar. American Journal of Primatology, vol. 28, no. 3, pp. 191-203. http://dx.doi.org/10.1002/ajp.1350280304.

PACHECO, E., 2011. Depredación de conos de Pinus patula Schl. et Cham, por la ardilla gris Sciurus aureogaster en el área forestal de Santiago Comaltepec, Oaxaca, México. Mexico: Universidad de la Sierra Juárez, 39 p. Bachelor's dissertation in Biology.

PALACIOS-MOSQUERA, Y., 2013. Especies de vertebrados asociados a la herviboría en Tillandsia carlos-hankii Matuda y su impacto en el éxito reproductivo en un bosque templado de Oaxaca, México. Mexico: Instituto Politécnico Nacional, 63 p. Master's dissertation in Conservation and Management of the Natural Resources.

PEDERASSI, J., LIMA, M.S.C.S., PEIXOTO, O.L. and SOUZA, C.A.S., 2012. The choice of bromeliads as a microhabitat by Scinax argyreornatus (Anura, Hylidae). Brazilian Journal of Biology $=$ Revista Brasileira de Biologia, vol. 72, no. 2, pp. 229-233. PMid:22735128.

SCHARF, W.C. and KREN, J., 1997. Summer diet of orchard orioles in southwestern Nebraska. The Southwestern Naturalist, vol. 42, no. 2, pp. 127-131.

SERVICIO METEOROLÓGICO NACIONAL, 2011 [viewed 10 June 2011]. Climatological normals of Mexico [online]. Mexico: SMN. Available from: http://smn.cna.gob.mx/climate.

SMITH, L.B. and DOWNS, R.J., 1977. Flora neotropica. USA: Hafner Press. 52 p. Monograph no. 14, part 2, Tillandsioideae (Bromeliaceae).

STILES, F.G. and SKUTCH, A.F., 1989. A guide to the birds of Costa Rica. USA: Comstock Publishing Associates. 511 p.

VAN STAN, J.T. 2nd. and PYPKER, T.G., 2015. A review and evaluation of forest canopy epiphyte roles in the partitioning and chemical alteration of precipitation. The Science of the Total Environment, vol. 536, pp. 813-824. http://dx.doi.org/10.1016/j. scitotenv.2015.07.134. PMid:26254081.

VICTORIA, V.N.V., 2009. Distribución de epifitas vasculares a lo largo de un gradiente altitudinal en Santa Catarina Ixtepeji, Oaxaca, México. Mexico: Instituto Politécnico Nacional, 68 p. Master's dissertation in Conservation and Management of the Natural Resources.

WAAL, C., BARRETT, S.C. and ANDERSON, B., 2012. The effect of mammalian herbivory on inflorescence architecture in ornithophilous Babiana (Iridaceae): implications for the evolution of a bird perch. American Journal of Botany, vol. 99, no. 6, pp. 1096-1103. http://dx.doi.org/10.3732/ajb.1100295. PMid:22615309.

ZACARÍAS-ESLAVA, Y. and CASTILLO, R.F., 2010. Comunidades vegetales templadas de la Sierra Juárez, Oaxaca: pisos altitudinales y sus posibles implicaciones ante el cambio climático. Boletín de la Sociedad Botánica de México, vol. 87, no. 1, pp. 13-28.

ZAR, D.H., 1999. Biostatistical analysis. USA: Pearson education.

ZOTZ, G., 2016. Plants on plants - the biology of vascular epiphytes. Germany: Springer. 282 p. http://dx.doi.org/10.1007/9783-319-39237-0.

ZOTZ, G. and HIETZ, P., 2001. The physiological ecology of vascular epiphytes: current knowledge, open questions. Journal of Experimental Botany, vol. 52, no. 364, pp. 2067-2078. http:// dx.doi.org/10.1093/jexbot/52.364.2067. PMid:11604445. 
ZOTZ, G. and RICHTER, A., 2006. Changes in carbohydrate and nutrient contents throughout a reproductive cycle indicate that phosphorus is a limiting nutrient in the epiphytic bromeliad, Werauhia sanguinolenta. Annals of Botany, vol. 97, no. 5, pp. 745-754. http://dx.doi.org/10.1093/aob/mcl026. PMid:16497701.

ZOTZ, G., 1999. What are backshoots good for? Seasonal changes in mineral, carbohydrate and water content of different organs of the epiphytic orchid, Dimerandra emarginata. Annals of Botany, vol. 84, no. 6, pp. 791-798. http://dx.doi.org/10.1006/ anbo.1999.0983.

ZOTZ, G., 2013. The systematic distribution of vascular epiphytes-a critical update. Botanical Journal of the Linnean Society, vol. 171, no. 3, pp. 453-481. http://dx.doi. org/10.1111/boj.12010. 